\title{
The Need for Improved Financial Reporting of a Developing Country Energy Utility
}

\author{
Alistair Brown \\ Curtin University, Western Australia \\ E-mail address: Alistair.Brown@cbs.curtin.edu.au
}

Telephone 61892661069

\begin{abstract}
Some consideration has been given to regulatory and institutional reforms to facilitate sustainable development in electricity usage in Papua New Guinea but little attention has been paid to bringing about full compliance of financial reporting expectations of the country's main energy utility. Examining documentary evidence of the audit reports of the Auditor General's Office of Papua New Guinea, this study considers the financial reporting compliance of PNG Power for the period 2007 to 2013, and the means by which compliant reporting may be improved. The results of the study reveal that the financial statements of PNG Power are late and receive disclaimers of opinion from the Auditor General's Office, which suggest that PNG Power's stakeholders are not receiving accurate and reliable financial information to make informed decisions about sustainable development of electricity usage and planning in Papua New Guinea. The study reveals that it would take little resources to improve PNG Power's reporting, which in turn could enhance national energy policy decision-making and energy utility accountability.
\end{abstract}

\section{Introduction}

This study explores the compliance of electricity supplier reporting and accountability in a developing country context by analyzing reporting issues that confront PNG Power Ltd (PNG Power) in meeting it functions to coordinate, distribute, generate, plan, transmit and sell the supply of electricity throughout Papua New Guinea (PNG). The study also considers the means by which reporting compliance and accountability of PNG Power could be improved, and thereby improving decision making for the sustainable development of energy provision in PNG. The objective of the review centers around the following research question: What challenges confront PNG Power Ltd in meeting its legislative reporting requirements? 
Financial reporting compliance is an important part of management of electricity supply in the Pacific [1]. Sound financial reporting enables key stakeholders to monitor energy efficiencies [2], execute long term policy and investment choices [3], scrutinize costs [4] and assess the effectiveness of asset-use [5]. The reporting by electricity utilities in low-income economies also allows management to showcase how they protect and monitor the state's key electricity infrastructure as well as facilitate regulatory and institutional reform [6].

However, the dependence on local level management for the reporting and accountability of state owned assets has a challenging history in emerging countries, particularly in Melanesian independent countries that have a deep tradition of professional reporting practice [7]. For a number of technical, economic, social and political reasons electricity supply in PNG remains "an extreme energy paradox" with abundant energy resources on the one hand [8] but with only a fifth of the population having access to energy sources on the other [9, p. 1532]. A further paradox in that the limited exploitation of energy sources has in turn enabled PNG to consume relatively little energy [10] and thus emerge as a low energy intense country. If energy intensity is measured in thousand British thermal units per 2005 international dollar, then PNG's energy intensity for 2010 is 3.4818 compared to the US's energy intensity of 7.6399 [11]. This relatively low energy intensity is further entrenched through the absence of a national grid and the use of hydropower for some provinces [12].

Some commentators [6] urge for direct rural electrification through regulatory and institutional reform, arguing that this initiative would help rural dwellers living in subsistence agricultural areas. One of the reasons put forward for this renewable and sustainable energy strategy is that there is a cost disincentive to providing an on-grid electrical investment in rural PNG partly because rural communities do not set aside money for periodic maintenance 
of non-current assets and partly because of a lack of technicians [6]. Yet, it is submitted that whatever form of electrification system is canvassed, it is important to make available a sufficiently reliable level of financial reporting information for broad policy strategists to make sound decisions for the sustainable growth of electricity supply across PNG. This is consistent with classical modernization theory which argues that practical development of an entity in a developing country arises from calculative reporting based on marginalist neoclassical precepts and full accountability [7]. In a Pacific Island Country context, it might well be argued that classical modernization theory rests behind what some commentators call the 'political economy of power sector reform' [13].

PNG Power Limited, formerly Elcom, the Electricity Commission, is an incorporated stateowned entity which falls under the Electricity Commission (Privatisation) Act 2002. PNG Power supplies electricity to most urban centres and some rural areas through hydropower stations, and some thermal stations. It enjoys monopoly status in this relatively small domestic market for power after being privatised in an era where the virtues of privatisation were framed in commercial imperatives. Under the Electricity (Amendment) Act, PNG Power approves licenses for electrical contractors, awards certification for models of electrical equipment and appliances for sale and provides safety advisory services and checks for major installations. The Independent Public Business Corporation (IPBC), acting as sole shareholder for the government, holds the shares of PNG Power as trustee of the General Business Trust. The board of PNG Power, consisting of eight directors appointed by IPBC, is supposed to provide regular financial and operational reports and a five-year business plan to IPBC on an annual basis. PNG Power also operates under the Companies Act 1997. The Constitution of PNG Power, established in compliance with this Act, explains the functions and responsibilities of the Board and the general administrative and reporting requirements. 
Generally, under a Westminster system of parliamentary democracy there is a duty placed upon energy utilities to provide a form of stewardship of the assets vested in them [14] and of improved energy efficiency [15]. This stewardship role is customarily reported through annual reports to parliament through a minister, allowing parliament to question the electricity supplier's financial activities and permitting a Public Accounts Committee to probe matters about the accounts. By opening up the financial statements of an electricity supplier to questioning, a considerable number of its stakeholders are able to gather information that is used for key decision-making [16] on profitability [17] sales volume and prices [18] and plant performance [19]. This information facilitates energy planning, investment in non-current assets such as buildings, grid appraisals, risk assessments, energy exploitations and costing of infrastructure. Reporting might also provide an account of what the academe describes as small-scale renewable energy [20]. Apart from conveying utility monetary value and cost-efficiency [21], reporting constructs interpretations of cost-cutting, competitive markets, pricing, tax-payer value, economic success, customer-focus, customer loyalty and best commercial practices.

PNG is not only a member of the Melanesian Spearhead Group but also a part of South East Asia [22]. As a consequence the results of the study will be of interest to electricity suppliers, electricity consumers, governments, environmentalists, international agencies, public and private sector entities and taxpayers of developing countries. It will also be of wide interest to other developing countries with an interest in reporting and accountability of electricity utilities as reporting's instrumental links with utilities is entrenched in calculations of costs, disposals, donations, purchase, valuations, revaluations, measure and disclosures of assets, as 
well as impressions of accountability and constructions of budgeting, planning, documentation and internal controls.

There is general recognition of the link between private energy companies and government departments [23] with an acknowledgement of the presence barriers of entry which may take the form of uncertain revenue streams, inability to finance projects, and long-term project risks such as grid encroachment [24]. To facilitate this link the government may play a role in providing strategy, market research, management of electricity consumption and production subsidies, loans for investment, private sector participation, and technical expertise [25]. It may also encourage private sector participation in the form of public-private partnership investments [26] although this may not be appropriate in some regions because of prevailing regulatory, technical and financial constraints [27, 28].

In some jurisdictions, the government supervises a private electricity utility through the management of renewable portfolio standards (RPS) ${ }^{1}$, feed-in tariffs (FIT) ${ }^{2}$, and direct subsidies [29]. All three mechanisms require the preparation of accurate and reliable audited accounts with a reliance on calculations of production for a RPS, baseline price ratios for a FIT and cost-benefits for direct subsidies.

In other jurisdictions, a government may increase its supervision through greater regulation and planning of targets [30], which also require accounting calculations of wholesale pricing, retail pricing, costs, revenues and profits. There is also space for governments to improve technical support, put in place more detailed regulations and apply strict penalties on

\footnotetext{
${ }^{1}$ Under a RPS, a retail electricity supplier may be required to procure a certain quantity of renewable energy. Under a mandatory RPS, an electricity supplier could face financial penalties if targeted quantities are not reached, particularly if the financial penalties are clearly defined.

${ }^{2}$ An FIT guarantees a price above market value setting baseline price ratios on calculations of $\$$ per $\mathrm{kWh}$.
} 
management for non-compliance. Governments may also use incentives, such as cash inducements, energy consumption subsidies and tax benefits to bring about compliant reporting. While it is possible that the existence of high generation costs, a lack of policy support and the presence of immature technologies may act as barriers for reporting compliance, these barriers might be overcome by improved mechanisms of incentives, punishments and supervision through energy targets, articulation of principal responsibilities, updated legislation and detailed monetary based penalties [31]. It is also possible for penalties to be imposed by a government if the electricity utility does not meet reporting standards. Such penalties may include the shutting down of the entity with the replacement of another, the taking away of any government compensation received by the electricity utility, and the intrusion of greater government supervision on the reporting process.

The paper now turns to the methods of the study, focusing particularly on textual analysis and the reporting expectations placed on PNG Power by national legislation. This is followed by the results of the study. Here a longitudinal approach is taken in recognition of the special set of circumstances facing local managers in a developing country context. A discussion of the results is then raised before a conclusion outlining energy policy implications is presented.

\section{Methods}

Acknowledging that textual analysis has a strong link with energy utility services [32-37], this study uses textual analysis to consider the reporting compliance of the PNG's main energy utility.

The methodological tool of textual analysis provides a unique form of evidentiary material of financial audit of energy utilities that facilitates textual evaluations [38] and synthesis for 
systematic review [39]. It contrasts with previous studies that use context analysis [40] to examine a large amount of textual information to derive quantitative understandings of phenomena. In this study, emphasis is given to deconstructing texts for qualitative understandings, laying bare the essential patterns arising from the analysis [41] for public policy awareness [42]. Such policies that impact on renewable energy and energy efficiency have far-reaching implications for economic competitiveness, energy security, human livelihood, climate change and pollution [29].

Case studies are widely used in sustainable energy analysis [25], particularly in a developing country setting with a focus on financial accounting issues [43]. This is important because there are many other locally run developing country energy utilities that may share a similar reporting milieu as those experienced by PNG Power. With this in mind, textual analysis takes into consideration context [44], particularly country [45] and local context which is critical in terms of public acceptance [46].

Given that a financial audit is an important method to protect the public interest, electronic data from the annual reports of the Auditor General's Office of Papua New Guinea (Auditor General) for 2007-2014 [47-54] were used to ascertain the reporting of PNG Power. Consistent with a checklist of aggregated accounting reporting used for a Pacific Island Country milieu [7], this study obtained reporting data from PNG Power, including the Auditor General's findings on the entity's financial statements, footnotes internal audit report, management report, segment reporting, related party transactions, summary of 
accounting policies, directors' report and account of revenue, expenditure, plant, property and equipment ${ }^{3}$.

Social representations are shaped by texts [55] and textual analysis endeavors to make sense of certain phenomena with a complex environment [56]. Consistent with the past literature's tracing of legal accountability of energy utilities [14], PNG Power's duty to report can be found from legal accountabilities constructed by the Companies Act 1997 and the Electricity Commission (Privatisation) Act 2002. The obligation to prepare an annual report, replete with financial statements falls under Sections 209 and 212 of the Companies Act 1997.

The Auditor General is also guided by Section 8(2) of the Audit Act 1989 (as amended). Deriving meanings from their domestic context, textual analysis takes into account the expectations of Part XI - Financial Reporting, Accounting Record and Audit - of the Companies Act 1997 which, as shown in Table 1, provides details of appointment and reappointment of auditors.

< Insert Table 2 here >

\footnotetext{
${ }^{3}$ A considerable number of reporting metrics that could be used by an electricity utility include financial performance indicators such as electricity sales (in gigawatt hours $[\mathrm{GwH}]$ ), gas sales (in terajoules [Tj]), total revenue (excluding interest), gross margin, earnings before interest, tax, depreciation and amortization (EBITDA), net profit after tax, net assets, EBITDA/total revenue (as a percentage), return on capital (as a percentage) and cost to serve customers (kina per customer). Sustainability reporting metrics might include: the number of environmental incidents per annum, carbon intensity ratio (such as the kilograms of carbon dioxide equivalent [ $\mathrm{kg} \mathrm{CO} 2 \mathrm{e}]$ per KWh electricity sent out), total greenhouse gas emissions (million tonnes CO2e), thermal efficiency (output as a percentage of energy input), capacity factor (energy produced as a percentage of the energy the plant could have produced while available), plant availability (amount of time plant was available to operate during the year, expressed as a percentage), forced outage factor (measure, expressed as a percentage, of losses of generation due to forced outages) and the amount of GWh generated. Further reporting calculations of the Reporting about the utility's customer call service, such as the total number of calls handled by a customer service representative, the percentage of calls answered within 30 seconds, and the percentage of calls abandoned
} 
Text is constructed to establish and maintain meanings (Ocelík and Osička, 2014). Sensitivity to the geographic, cultural and economic context of reporting is included in the textual analysis. The reporting compliance instruments of the Constitution of PNG, Audit Act 1989 (amended 1995), Companies Act 1997 and Electricity Industry Act 2002 make up part of the national legislation of PNG emphasize accurate and timely information.

For each annual report, textual analysis ascertained the type of audit opinion received by PNG Power. In this context, PNG Power's financial statements could have received one of four audit opinions: an unqualified opinion, indicating that PNG Power's financial statements were presented fairly and conformed with generally accepted accounting principles; a qualified opinion, where PNG Power's financial statements were limited in scope and did not conform with accounting principles such that the auditor was unable to obtain sufficient evidence of the entity's transactions; a disclaimer opinion, where insufficient evidence existed to form an audit opinion due to scope limitation or uncertainties; and an adverse opinion.

\section{Results}

The results of the study revealed that PNG Power's financial statements from year ending 2007 to 2013 invariably received a disclaimer of opinion from the Auditor General, with all financial statements either handed in late for audit or still to be handed in for audit.

The disclaimer of opinion received for PNG Power's financial statements for year ending 2007 arose because management of PNG Power had prepared inaccurate and incomplete 
accounts related to capital works-in-progress and property, plant and equipment [48]. In terms of the capital works-in-progress account no documentation was furnished to the Auditor General on the costs incurred for the capital works. As a consequence, the carrying value of capital work-in progress of K220 million could not be verified.

The Auditor General also received incomplete documentation of PNG Power's property, plant and equipment, valued in the accounts by PNG Power at K136 million, and again was unable to verify the valuation. Indeed, the Auditor General noted that the physical verification of property, plant and equipment missed certain items, making it difficult to substantiate the depreciation expenses allocated to property, plant and equipment. The lack of accuracy of the property, plant and equipment account and related depreciation expense account weakens both the validity of the balance sheet, which displays PNG Power's assets, liabilities and equity, and the profit and loss account, which displays PNG Power's revenue and expenses to derive profit.

The Auditor General was also unable to confirm the accuracy of the inventory account because of a lack of documentation. This further undermined the reliance placed on the accuracy of PNG Power's balance sheet. Further, records were not kept to support calculations of income tax balances, thus eroding PNG Power's after tax result in the profit and loss statement. In addition to incomplete documentation and records, the Auditor General detected in PNG Power a number of internal control weaknesses. Lack of internal controls in PNG Power's payroll system casts doubt about the accuracy of PNG Power's calculation of salaries expenses and superannuation deductions. Furthermore, there were difficulties detected in PNG Power's credit control and debt management systems. For 
instance, by the year-end 2007, PNG Power was owed approximately K81 million by its customers for the consumption of electricity. Just over half this amount (K42 million) was at least six months old. Management of PNG Power responded to this finding by saying the company was putting resources into improving its credit control and debt management processes.

The Auditor General also recommended that PNG Power should strengthen its billing processes as incorrect tariff rates were being used to bill customers, and customers' track records were not being investigated. There also appeared to be a lack of documentation kept about electricity connections and meters and no management reports were maintained about billing processes. The Auditor General also found there was inadequate control over meter equipment. Faulty meters were not replaced and illegal connections were not addressed leading to revenue losses.

Average power loss for ratio for 2007 was 17\% (2006: 17\%) which equated to around K81 million. A high loss ratio of $26.5 \%$ was experienced in August and a low of $10.5 \%$ in November. The losses are considered significant [48, p. 209].

The Auditor General expressed concerns about PNG Power's processes on purchases and accounts payable system (for example, variances were detected between supplier statements and PNG Power's payments) and on reconciliation procedures, particularly in regards to fuel, one of the major cost items of PNG Power:

We noted no evidence of system quantities with physical readings, independently verified by the head office personnel [48, p. 211]. 
It was further found that PNG Power was exposed to penalties for late lodgment of corporate tax returns (by year ending 2009, returns for year-ending 2005, 2006 and 2007 were outstanding), GST returns (returns for the years ending 1999-2004 were not lodged raising a retrospective bill from the IRC of K24 million, with repayments required at K500,000 per month), and business withholding taxes.

PNG Power's financial statements for year ending 2008 also received a disclaimer of opinion [51]. The Auditor General found there was a lack of documentation for capital projects in progress of K125 million. In particular the Auditor General questioned the appropriateness of capitalizing K8.8 million administration costs. The Auditor General [51, p. 228] "also identified a difference of K10.9 million existing between the general ledger and the project sub-ledgers". The accuracy of K719 million worth of property, plant and equipment and K30 million worth of depreciation expense could not be confirmed by the Auditor General, throwing into doubt the profit figure of K15 million. Documentation was also missing for K30.3 million of inventories.

There was also difficulty in reconciling PNG Power's trade payable accounts with its suppliers' statements, including a variance of K14.3 million in relation to a fuel supplier. Documentation was missing for K13.3 million of trade payable accounts, and there were incomplete records of income tax balances. Salaries and wages taxes were also not properly deducted on PNG Power's allowances and gratuities paid to its employees. Further, there were problems in verifying 
tax and superannuation deductions, and whether these have been appropriately charged and remitted to the respective authorities with the applicable legislation [51, p. 230].

PNG Power also received a K1 million grant from the government towards rural electrification projects but did not supply any information and documentation about how the conditions of the grant were complied with. As a consequence, it appeared PNG Power made an inappropriate decision to record this grant as revenue. The Auditor General also observed that PNG Power was owed over K70 million by customers for electricity consumption, of which K28 million (40 per cent of total debt) was doubtful debts, "suggesting that credit control and debt management requires significant improvement" [51, p. 231]. PNG Power's management acknowledged that K15 million could be potentially written off as bad debts (K17 million to be confirmed as irrecoverable for year ending 2008).

A further observation from the Auditor General was that internal control procedures for PNG Power's billing system needed to be improved "to avoid the risk of revenue losses and other irregularities" [33, p. 231]. Illegal electricity connections continued to raise internal control difficulties for PNG Power:

The average power loss ratio for the year 2008 was 19\% (2007: 17\%) which equated to around K100 million (2007: K81 million) [51, p. 231].

Other internal control procedures that created difficulties for PNG Power included:

Incorrect tariff rates being used to bill customers, inadequate control over meter equipment, faulty meters not replaced on a timely basis, unregistered customers not investigated and validated on a timely basis, inadequate documentation over new 
electricity connections and meters on estimate basis not finalized on a timely basis [51, p. 231].

In addition, PNG Power's corporate tax returns for 2006 and 2007 had not been completed, GST returns for 1999 to 2004 had not been lodged, and K3.4 million worth of fuel stock was written off because of poor internal control procedures.

PNG Power's financial statements for the year ended 2009 also received a disclaimer of opinion from the Auditor General [52]. There were inaccuracies and incomplete balances of capital work in progress, inventory, property, plant and equipment, taxes, and trade creditors. The Auditor General could not verify K157 million of capital works-in-progress because documentation was missing. Property, plant and equipment for year ending 2009 was stated at K860,403,000 but again it was difficult for the Auditor General to verify this amount because of lack of documentation and the inaccuracies of calculations of capitalized project costs. Reconciliation of PNG Power's operating bank account found that there were a significant number of negative unpresented cheques of approximately $\mathrm{K} 3$ million and payments appearing on the bank statement of approximately K7 million not yet processed into the general ledger system [52; p. 211].

Documentation was also missing for prepayments made to overseas and fuel suppliers, other receivables, trade payables, payroll and employee entitlements, and general stores inventory. In particular, there was insufficient evident provided by PNG Power for its adjustment of K13,259,968 worth of fuel inventory. Further, the Auditor General was concerned that there 
was a variance of K17 million between the trade payable of K43 and supplier report balance of K26 million. Income tax returns for the years ending 2006 to 2008 had not been lodged.

The disclaimer of opinion formed on PNG Power's financial statements for the year ending 2010 was based on similar concerns as raised in previous years. Once again, the Auditor General [53] recommended that PNG Power should improve its credit control and debt management processes. K72 m was owed to PNG Power by its customers, of which K28M (38 per cent) was considered doubtful. The Auditor General also recommended that PNG Power improved its billing and revenue system as power loss was 19\% or K117 million.

The Auditor General also found reconciliations also needed to be improved for the trade payable account (which had an unreconciled variance of $\mathrm{K} 17 \mathrm{~m}$ ) and general ledger system, and internal controls needed to be strengthened for purchases, payables and fuel stock.

PNG Power's financial statements for the years ending 2011 and 2012 contained a similar basis of disclaimer of audit opinion. For the year ending 2011, the AGOPNG found inaccuracies and incompleteness in

the opening balances of capital work in progress, property, plant and equipment, trade receivables, trade creditors, cash and cash equivalents, inventory, other payables, other receivables, employee entitlements and tax balances [53, p. 222]. 
These inaccuracies impacted on the results represented in PNG Power's 2013 financial statements [54]. In particular, the Auditor General was unable to confirm PNG Power's capital work-in-progress account because documentation was missing for K94 million worth of capital work-in-progress. Also, it was difficult for the Auditor General to verify the amount of depreciation on K190.1 million of transferred property, plant and equipment as there was no evidence about when these assets were available for use. There was also no documentation for K32.8 million of inventory as well as for K2.12 million of inventory obsolescence. Moreover, no effort had been made to provide the Auditor General with the net realizable value of inventory.

There also appeared considerable internal control weaknesses in the accounting for electricity income and cash. The amount of electricity revenue recorded by PNG Power was in excess of K20.2 million recorded in the general ledger. The Auditor General was unable to confirm K26.7 million of cash due to inadequate documentation. Indeed, it appeared the Auditor General was unable to verify substantial amounts of other receivable, trade payables, customer advances, employee entitlements, income tax balances and thus the financial position of PNG Power. Further, the Auditor General noted significant control weaknesses in electronic accounting information systems.

\section{Discussion}

In terms of the objective of the study, the findings of the Auditor General clearly show that there are considerable challenges facing PNG Power in meeting the written reporting and financial accountability expectations placed upon it by national legislation. The continual disclaimer opinions raised by the Auditor General over PNG Power's accounts indicates there was insufficient evidence provided by PNG Power to form an audit opinion of the energy 
utility. The lack of reporting undermines PNG Power's ability to coordinate, distribute, generate, plan, transmit and sell the supply of electricity throughout the country. It is difficult to coordinate the selling or supply of electricity if an entity does not have sufficient documentation and internal controls to look after its key current and non-current assets. The generation and distribution of the sale and supply of electricity is further weakened by the complete lack of physical controls over the continual power loss over the time period of the study. In this respect the lack of internal controls proved costly. For example, average power loss ratios were $17 \%$ for year ending 2006 and 2007, and climbed to $19 \%$ for year ending 2008 and 2009.

Financial planning by PNG Power was also hampered by the inaccuracies and incomplete balances of capital works in progress, inventory, property, plant and equipment, taxes and trade creditors. This is a critical issue. The lack of documentation puts in doubt the stated carrying value of capital work-in-progress. The process of selling of electricity is also weakened by the lack of billing processes and reconciliations. The most elementary form of reporting - the keeping of source documents to verify underlying transactions of PNG Power - was not maintained throughout the study period. Thus, it was not possible for the Auditor General to verify large amounts of PNG's property, plant and equipment and inventory because source documents were missing.

A further challenge confronting PNG Power was the difficulty in preparing timely financial reports for audit inspection. This meant the Auditor General was making audit opinions two or three years after the reports were supposed to be completed. The lack of timely information not only affects internal management decision-making but also impacts on the 
decision-making of PNG Power's external stakeholders including multilateral aid organizations, banks, government policy makers and ministers.

A disquieting finding from the analysis is the exposure to PNG power to penalties from the IRC of PNG for non-lodgment of corporate tax returns and GST returns, and late repayments to the IRC. This not only affects PNG Power's current tax liability for any given financial year but also its future tax liabilities. From an internal point of view, this impacts on the current and future balance sheets of PNG Power and potentially falls foul of any debt covenants it might have in place with loans from financial institutions, which in turn may trigger penalty costs in terms of higher interest rates. However, there is a much greater issue at stake here. From an external point of view, taxpayer funds were used by the PNG government to set up and maintain the operations of PNG Power. It is not unreasonable for PNG funders (for example, taxpayers, overseas aid agencies and the national government) to expect PNG Power to pay corporate tax on a timely basis.

\section{Conclusion and Policy Implications}

There are a number of implications for policy makers of PNG Power arising from these results. It is important for utility management to make an effort to improve its reporting compliance through familiarity with local legislation that requires information for reasons of oversight and governance. There is also an opportunity for parliamentary committees, such as the Public Accounts Committee, and ministerial entities, such as the Minister of Energy, to urge PNG Power's management to respond more rigorously to the concerns of the Auditor General. In this way, local management could be held more accountable for the reporting performance both to the state auditor and oversight bodies. This monitoring could be 
supported by the introduction of detailed regulations on the reporting expectations of PNG Power through the imposition of reporting targets [30], the application of monetary based penalties [31] for disclaimed, qualified or adverse financial statements and the introduction of incentives for unqualified audited financial statements. These initiatives may prove particularly effective if the targets, monetary-based penalties and incentives were placed upon the directors and senior management of PNG Power.

There appears to be considerable merit for the national government in maintaining, and possibly extending, the financing of the state auditor for the probing of a state owned energy utility. In the case of PNG Power, considerable clarity was provided by the Auditor General on reporting issues that needed to be met by utility managers. A well-funded state audit office offers a relatively inexpensive mechanism by which to monitor and help improve the reporting performance of an electricity utility at the local level. Greater links with regional audit offices such as the Pacific Association of Supreme Audit Institutions may also help improve local level auditing through the provisions of training and advice on procedures and reporting products connected with the audit process.

The results of the study may prove useful to stakeholders of other developing country energy utilities. In serving the needs of their clients, it is important not only for management to comply with the reporting expectations of local legislation but also for national governments and their agencies to consider state audit reports in assessing the performance of an energy utility. In this way, national government entities may take measures to ensure reporting of an energy utility is conducted on a timely and accurate basis so that useful decisions may be based on reliable information. External government and non-government donors also need to pay attention to the reporting compliance of developing country energy utilities, particularly given the limited availability of donor funds and the competing uses of those funds. 


\section{References}

[1] Mishra V, Sharma S, Smyth R. Are fluctuations in energy consumption per capita transitory? Evidence from a panel of Pacific Island countries. Renew Sustain Energ Rev 2009;37:2318-2326.

[2] Scholtens B, Kleinsmann R. Incentives for subcontractors to adopt $\mathrm{CO}_{2}$ emission reporting and reduction techniques. Energ Policy 2011;39:1877-1883.

[3] Grubert E. 2012. Reserve reporting in the United States coal industry. Energ Policy 2012;44:174-184.

[4] Elaes E, Meskens G, van der Sluijs PJ. On the contribution of external cost calculations to energy system governance: The case of a potential large-scale nuclear accident. Energ Policy 2011;39:5664-5673.

[5] Raineri R. Asset life and pricing the use of electricity transmission infrastructure in Chile. Energ Policy 2010;38:30-41.

[6] Dornan M. Access to Electricity in Small Island Developing States of the Pacific: Issues and Challenges. Renew Sustain Energ Rev 2014:31:726-735.

[7] Brown AM. Reporting Compliance of National Fisheries Authority of Papua New Guinea. Mar Policy 2015;51:196-201.

[8] Owen AD, Lattimore JC. Oil and gas in Papua New Guinea. Energ Policy 1998;26:655660.

[9] Sovacool BK, D'Agostino AL, Bambawale MJ. The socio-technical barriers to Solar Home Systems (SHS) in Papua New Guinea: "Choosing pigs, prostitutes, and poker chips over panels". Energ Policy 2011;39:1532-1542.

[10] Pearman GI, Limits to the potential of bio-fuels and bio-sequestration of carbon. Energ Policy 2013;59:523-535.

[11] Wang, C. Changing energy intensity of economics in the world and its decomposition. Energ Econ 2013;40:637-644.

[12] Nagai Y, Yamamoto H, Yamaji K. Construction low emitting power systems through grid extension in Papua New Guinea (PNG) with rural electrification. Energy 2010;35:23092316.

[13] Dornan M. Reform Despite Politics? The Political Economy of Power Sector Reform in Fiji, 1996-2013. Energ Policy 2014:67:703-712.

[14] Conrad L, Price CW. New accountabilities in utilities: fifty years of legal accountability in the gas industry. Energ Policy 2001;29:1357-1361. 
[15] Gude VG. Energy and water autarky of wastewater treatment and power generation systems. Renew Sustain Energ Rev 2015;45:52-68.

[16] Sovacool BK. A qualitative factor analysis of renewable energy and Sustainable Energy for All (SE4ALL) in the Asia-Pacific. Energ Policy 2013;59:393-403

[17] Caralis G, Diakoulaki D, Yang P, Gao Z, Zervos A, Rados K. Profitability of wind energy investments in China using a Monte Carlo approach for the treatment of uncertainties. Renew Sustain Energ Rev 2014;40:224-236.

[18] Sgroi F, Di Trapani A, Foderà M, Testa R, Tudisca S. Economic assessment of Eucalyptus (spp.) for biomass production as alternative crop in Southern Italy. Renew Sustain Energ Rev 2015;44: 614-619

[19] Milosavljević DD, Pavlović TM, Piršl DS. Performance analysis of A grid-connected solar PV plant in Niš, republic of Serbia. Renew Sustain Energ Rev 2015;44:423-435.

[20] Pachauri S, Energy access, poverty, and development: the governance of small-scale renewable energy in developing Asia. Energy 2014;68:1007-1008.

[21] Schlomann B Schleich J. Adoption of low-cost energy efficiency measures in the tertiary sector - An empirical analysis based on energy survey data. Renew Sustain Energ Rev 2015;43:1127-1133.

[22] Daioglou V, van Ruijven BJ, van Vuuren DP. Model projections for household energy use in developing countries. Energy 2012;37:601-615.

[23] Shami SH, Ahmad J, Zafar R, Haris R, Bashir S. Evaluating wind energy potential in Pakistan's three provinces, with proposal for integration into national power grid. Renew Sustain Energ Rev 2016;53:408-421.

[24] Williams NJ, Jaramillo P, Taneja J, Ustun TS. Enabling private sector investment in micro grid-based rural electrification in developing countries: A review. Renew Sustain Energ Rev 2015;52:1268-1281.

[25] Aslani A, Naaranoja M Zakeri B. The prime criteria for private sector participation in renewable energy investment in the Middle East (case study: Iran). Renew Sustain Energ Rev 2012;6:1977-1987.

[26] Shaikh F, QiangJi, Q, Fan Y. The diagnosis of an electricity crisis and alternative energy development in Pakistan. Renew Sustain Energ Rev 2015;52:1172-1185.

[27] Manos B, Partalidou M, Fantozzi F, Arampatzis S, Papadopoulou O. Agro-energy districts contributing to environmental and social sustainability in rural areas: Evaluation of a local public-private partnership scheme in Greece. Renew Sustain Energ Rev 2014;29:8595. 
[28] Manos B, Bartocci P, Partalidou M. Fantozzi F, Arampatzis S. Review of public-private partnerships in agro-energy districts in Southern Europe: The cases of Greece and Italy,.Renew Sustain Energ Rev 2014;9:667-678.

[29] Lo K. A critical review of China's rapidly developing renewable energy and energy efficiency policies. Renew Sustain Energ Rev 2014;29:508-516.

[30] Zhang H, Ozturk UA, Wang Q, Zhao Z. Biodiesel produced by waste cooking oil: Review of recycling modes in China, the US and Japan. Renew Sustain Energ Rev 2014;38:677-685.

[31] Xin-gang Z, Tian-tian F, Lu C, Xia F. The barriers and institutional arrangements of the implementation of renewable portfolio standard: A perspective of China. Renew Sustain Energ Rev 2014;30:371-380.

[32] Spyridaki NA, Flamos A. A paper trail of evaluation approaches to energy and climate policy interactions, Renew Sustain Energ Rev 2014;40: 1090-1107.

[33] Sovacool BK. Energy policy and cooperation in Southeast Asia: The history, challenges, and implications of the trans-ASEAN gas pipeline (TAGP) network. Energ Policy 2009;37:2356-2367.

[34] Kratochvíl P, Tichý L. EU and Russian discourse on energy relations. Energ Policy 2013;56:391-406.

[35] Cambini C, Franzi D. Independent regulatory agencies and rules harmonization for the electricity sector and renewables in the Mediterranean region. Energ Policy 2013;60:179-191.

[36] Kirkels AF .Discursive shifts in energy from biomass: A 30 year European overview. Renew Sustain Energ Rev 2012;16:4105-4115.

[37] Sengers F, Raven RPJM,Van Venrooij A. From riches to rags: Biofuels, media discourses, and resistance to sustainable energy technologies. Energ Policy 2010;38:50135027.

[38] Young CY, Huang, WM. Review of Taiwan's climate policy after Copenhagen. Renew Sustain Energ Rev 2012;16:20-28.

[39] Barrios-O’Neill D, Schuitema G. Online engagement for sustainable energy projects: A systematic review and framework for integration. Renew Sustain Energ Rev 2016;54:16111621.

[40] Yuan H, Lu W, Hao JJ. The evolution of construction waste sorting on-site. Renew Sustain Energ Rev 2013;20:483-490. 
[41] Jones J, Shanks A. Laid Bare: Religious intolerance within online commentary about 'Bare Below the Elbows'. Health Care Anal 2013;21:271-281.

[42] Bail K, Cook R., Gardner A, Grealish L. Writing ourselves into a web of disobedience: A nursing policy analysis. Int J Nurs Stud 2009;46:1457-1466.

[43] Abdul-Salam Y, Phimister E. The politico-economics of electricity planning in developing countries: A case study of Ghana, Energ Policy 2016;88:299-309.

[44] Qiu H, Sun L, Huang J, Rozelle S. Liquid biofuels in China: Current status, government policies, and future opportunities and challenges. Renew Sustain Energ Rev 2012;16:30953104.

[45] Ismail MS, Moghavvemi M, Mahlia TMI. Energy trends in Palestinian territories of West Bank and Gaza Strip: Possibilities for reducing the reliance on external energy sources. Renew Sustain Energ Rev 2013;28:117-129.

[46] Dalton G, Allan G, Beaumont N, Georgakaki A, Hacking N, Hooper T, Kerr S, O’Hagan AM, Reilly R, Ricci P, Sheng W, Stallard T. Economic and socio-economic assessment methods for ocean renewable energy: Public and private perspectives. Renew Sustain Energ Rev 2015; 45:850-878.

[47] AG 2007. Independent Audit Report on the Auditor General's Office for the year ended 31 December 2006. Auditor-General's Office of Papua New Guinea. Port Moresby, Papua New Guinea.

[48] AG 2008. Report of the Auditor-General- 2007 on the public accounts and the control of and on transactions with or concerning the public moneys and property of Papua New Guinea, Part IV, Section A - Public bodies and their subsidiaries. Auditor-General's Office of Papua New Guinea. Port Moresby, Papua New Guinea.

[49] AG 2009. Report of the Auditor-General - 2008 on the public accounts and the control of and on transactions with or concerning the public moneys and property of Papua New Guinea, Part IV, Section A - Public bodies and their subsidiaries. Auditor-General's Office of Papua New Guinea. Port Moresby, Papua New Guinea.

[50] AG 2010. Report of the Auditor-General - 2009 on the public accounts and the control of and on transactions with or concerning the public moneys and property of Papua New Guinea, Part IV, Section A - Public bodies and their subsidiaries. Auditor-General's Office of Papua New Guinea. Port Moresby, Papua New Guinea.

[51] AG 2011. Report of the Auditor-General - 2010 on the accounts of public authorities and statutory bodies established under the act of parliament and government owned companies established under the Companies Act, Part IV, Public bodies and their subsidiaries, national government owned companies, national government shareholdings in other companies. Auditor-General's Office of Papua New Guinea. Port Moresby, Papua New Guinea. 
[52] AG 2012. Report of the Auditor-General - 2011 on the accounts of public authorities and statutory bodies established under the act of parliament and government owned companies established under the Companies Act, Part IV, Public bodies and their subsidiaries, national government owned companies, national government shareholdings in other companies. Auditor-General's Office of Papua New Guinea. Port Moresby, Papua New Guinea.

[53] AG 2013. Part 4 Report of the Auditor-General 2012 on the accounts of public authorities and statutory bodies established under the act of parliament and government owned companies established under the Companies Act: public bodies and their subsidiaries, national government owned companies, national government shareholdings in other companies. Auditor-General's Office of Papua New Guinea. Port Moresby, Papua New Guinea.

[54] AG 2014. Part 4 Report of the Auditor-General 2013 on the accounts of public authorities and statutory bodies established under the act of parliament and government owned companies established under the Companies Act: public bodies and their subsidiaries, national government owned companies, national government shareholdings in other companies. Auditor-General's Office of Papua New Guinea. Port Moresby, Papua New Guinea.

[55] Ocelík P, Osička J. The framing of unconventional natural gas resources in the foreign energy policy discourse of the Russian Federation. Energ Policy 2014;72, 97-109.

[56] Thiel CE, Bagdasarov Z, Harkrider L, Johnson JF, Mumford MD. Leader Ethical Decision-Making in Organizations: Strategies for Sensemaking. J Bus Ethics 2012;107:49-64. 